\title{
Parental perceptions towards passive smoking: a cross-sectional survey in Vikarabad town, India
}

\author{
*K S Poornima ${ }^{1}$, P Parthasarathi Reddy ${ }^{2}$, M Shakeel Anjum², M Monica ${ }^{2}$, K Yadav Rao $^{2}$, Irram Abbas $^{2}$
}

Sri Lanka Journal of Child Health, 2016: 45(1): 24-31

\begin{abstract}
Background: Environmental tobacco smoke is a known human carcinogen and passive smoking has now emerged as a health threat. Home is the major source of exposure to tobacco smoke among children.

Objective: To explore parents' smoking behaviour and their perceptions towards passive smoking and its effects on their children.
\end{abstract}

Method: A cross-sectional, household survey was conducted on 179 smoking parents in an Indian town using a semi-structured questionnaire which gathered information about demographic factors and 21 questions assessing their smoking behaviour and perceptions about passive smoking.

Results: Thirty two percent reported that they did not know smoking caused cancer and only $25 \%$ strongly believed that if parents smoked, it had a harmful effect on children's health.

Conclusion: Low education, unskilled jobs and a past experience of smoking related health problems have an influence on the way passive smoke and its harmful effects are perceived by smoking parents.

DOI: http://dx.doi.org/10.4038/sljch.v45i1.8081

(Keywords: Passive smoking, second-hand smoke, tobacco smoke, parents, perceptions)

${ }^{1}$ Senior Resident, Department of Public Health Dentistry, Government Dental College and Hospital, Hyderabad, Telangana, India.

${ }^{2}$ Department of Public Health Dentistry, Sri Sai College of Dental Surgery, Vikarabad, India.

*Correspondence: poornimakistigari@gmail.com

(Received on 10 February 2015: Accepted after revision on 20 March 2015)

The authors declare that there are no conflicts of interest

Personal funding was used was used for this project.

Open Access Article published under the Creative

Commons Attribution CC-BY (cc) (i) License.

\section{Introduction}

Smoking is, at present, the principal avoidable cause of premature death in the world ${ }^{1}$. By the year 2030, according to current trends, it is assumed that this number will increase to ten million with $70 \%$ of deaths occurring in low and middle income countries ${ }^{2}$.

Breathing in other people's smoke is called passive, involuntary or second-hand smoking. United States Environmental Protection Agency (EPA) in 1993 designated environmental tobacco smoke as a "Class A" or known human carcinogen (the Agency's category of greatest scientific certainty for known or suspected carcinogens) $)^{3}$.

Although children get exposed outside the home, tobacco smoke is the commonest indoor environmental pollutant to which they are exposed. Most of their time is spent at home and indoors, so, the primary sources are parents and other household members. Passive smoking is a cause of bronchitis, pneumonia, coughing and wheezing, asthma attacks, middle ear infection, cot death, and possibly cardiovascular and neurobiological impairment in children ${ }^{4}$. Because the lungs develop rapidly in early life, any insult during this sensitive period may affect growth and future lung function ${ }^{5}$. Unlike adults, children lack the ability to confront smokers.

There is no safe level of tobacco smoke exposure ${ }^{6}$. The severity of the health impact of tobacco smoke exposure on children has led the World Health Organisation to call for the right of every child to grow up in an environment free of tobacco smoke ${ }^{7}$. Despite knowing the risks to their children's health, parents continue to expose their children to tobacco smoke.

\section{Objective}

The objective of this study was to assess the parents' perceptions about passive smoking and its consequences as well as their intention of quitting smoking. 


\section{Method}

A cross-sectional survey was conducted on smoking parents of an Indian town. For the collection of data, a semi-structured questionnaire was used. It was validated (item content validity $=0.79$ ). A pilot study was conducted on 30 smoking parents in households of two areas of the town, to test for its reliability $(\alpha=$ 0.602 ) as well as the feasibility of conducting the survey. The questionnaire consisted of three sections: a) socio-demographic data of the parents b) their smoking status and family characteristics c) perceptions towards passive smoking and their intention to quit. Perception-based questions were scored on a 5-point Likert scale, ranging from 1 (strongly agree) to 5 (strongly disagree).

Using purposive sampling, ten areas of the town were selected. Every household in each of the ten areas was surveyed. The inclusion criteria were parents having a habit of smoking any form of tobacco and those living with children of school-going age. In every area, households with the subjects meeting the inclusion criteria were approached. Subjects not willing to participate; those not currently smoking and those not living with children were excluded. Every household in each of the ten areas was surveyed. One thousand one hundred and seventy households were found to have smokers and among them, 179 smoking subjects constituted the final sample. The study was systematically scheduled for a period of one month from $31^{\text {st }}$ August to $30^{\text {th }}$ September 2013. The Institutional Review Board of the Sri Sai College of Dental Surgery, Vikarabad of Telangana State granted ethical clearance.

The survey was conducted by one of the authors and an assistant. The assistant was given a brief training in communication skills. The survey was carried out during daytime between $10 \mathrm{am}$ and $5 \mathrm{pm}$. Each household survey began with an introduction of the author and an explanation of the purpose of conducting the survey to the person opening the door who was later asked, "Does anyone who lives here smoke?" If the answer was yes, the respondent was asked if the person who smoked was a parent and if there were any young children living in the same house. If the answer was yes again, informed consent was obtained orally.

After explanation about the purpose of the survey, questionnaires were given to the subjects, in English or the local language, based on their preference. Each subject took an average of 10 minutes and questionnaires were collected back on the same day. If subjects were not immediately present, an appointment was scheduled to get the questionnaire filled by them later. Two attempts were made to contact the subjects and thereafter, they were excluded. For subjects who were unable to read or write, questions were read to them along with the possible responses and the respondent's answers were marked on the questionnaire. For the subjects' convenience and privacy, any discussion regarding the survey was done in the absence of their children.

Data collected were entered in Microsoft Excel sheet and statistically analysed using Statistical Package for Social Science, (SPSS) version 17.0. Frequency and percentage scores were calculated. The responses for 'strongly agree' and 'strongly disagree' were clubbed with 'agree' and 'disagree', respectively. Chi-square test was performed to analyse the significance of the differences between categorical variables. Level of significance was set at $\mathrm{P}<0.05$.

\section{Results}

\section{Table 1}

Distribution of subjects based on smoking status, family characteristics \& past experience of smoking related health problems

\begin{tabular}{|l|c|}
\hline \multicolumn{1}{|c|}{ Variable } & No (\%) \\
\hline Type of product smoked & \\
Cigarettes & $89(50)$ \\
Beedi & $74(41)$ \\
Both & $16(09)$ \\
Other & $00(00)$ \\
\hline Another smoker in the family & \\
Yes & $43(24)$ \\
No & $136(76)$ \\
\hline Number of children in the family & \\
One & $62(35)$ \\
More than one & $117(65)$ \\
\hline Age of children & $154(86)$ \\
15 years or less & $25(14)$ \\
More than 15 years & \\
\hline Number of cigarettes smoked per day & $84(47)$ \\
$0-5$ & $42(23)$ \\
$6-10$ & $53(30)$ \\
More than 10 & \\
\hline Weekly expenditure on smoking products & $53(30)$ \\
$<50$ rupees & $66(37)$ \\
Rs.51 - Rs. 100 & $60(33)$ \\
\hline Rs. 100 & \\
\hline Health problems experienced in the past & $95(53)$ \\
year & $34(19)$ \\
None & $26(15)$ \\
Coughing & $17(09)$ \\
Shortness of breath & $07(04)$ \\
Chest pain & \\
Other & \\
\hline
\end{tabular}

Table 1 presents the distribution of the subjects based on their smoking status, family characteristics and 
their past experience of any smoking related health problems. All 179 subjects were male and 25\% were aged between 20 and 30 years. More than half of the subjects $(56 \%)$ had only a high school education and
$46 \%$ were working in unskilled jobs (as labourers and farmers). Table 2 shows the distribution of subjects based on their views about passive smoking.

Table 2: Distribution of subjects based on their views about passive smoking

\begin{tabular}{|l|c|c|c|}
\hline \multicolumn{1}{|c|}{ Statement } & $\begin{array}{c}\text { Agree } \\
\text { No. (\%) }\end{array}$ & $\begin{array}{c}\text { Don't know } \\
\text { No. (\%) }\end{array}$ & $\begin{array}{c}\text { Disagree } \\
\text { No. (\%) }\end{array}$ \\
\hline Enjoy smoking & $114(64)$ & $20(11)$ & $45(25)$ \\
\hline Smoking causes oral cancer & $79(44)$ & $57(32)$ & $43(24)$ \\
\hline If parents smoke, it does not have any harmful effect on children's health & $66(37)$ & $36(20)$ & $77(43)$ \\
\hline Smoking in the presence of children should be avoided & $149(83)$ & $13(07)$ & $17(10)$ \\
\hline Some amount of smoke from my cigarette will affect my children's health & $117(65)$ & $37(21)$ & $25(14)$ \\
\hline Smoke anywhere indoors even in the presence of children & $87(49)$ & $08(04)$ & $84(47)$ \\
\hline Feeling of guilt & $126(71)$ & $22(12)$ & $31(17)$ \\
\hline Children show immediate signs of discomfort & $113(64)$ & $33(18)$ & $33(18)$ \\
\hline Put cigarettes off due to discomfort to children around & $130(72)$ & $12(07)$ & $37(21)$ \\
\hline Concerned that children might get influenced & $138(77)$ & $12(07)$ & $29(16)$ \\
\hline Anti-tobacco advertisements inspire on quitting smoking & $147(82)$ & $07(04)$ & $25(13)$ \\
\hline My child has asked me to stop smoking many times & $145(81)$ & $10(06)$ & $24(13)$ \\
\hline This study has encouraged to think about stopping smoking & $154(86)$ & $15(08)$ & $10(06)$ \\
\hline Will definitely quit smoking for family's sake & $12(07)$ & $07(04)$ \\
\hline
\end{tabular}

A statistically significant difference was seen among the age groups and a past health experience in relation to their perception towards passive smoking. The younger subjects were more concerned about the harmful effects of smoking on themselves and their children $(\mathrm{P}<0.05$, Table 3$)$. Subjects who had a past experience of smoking related health problems poorly perceived the harmful effects of this habit $(\mathrm{P}<0.001)$. On the other hand, those aware about the harmful health effects of smoking were the ones who had not experienced such problems.
Table 4 shows the association of socio-demographic and the smoking characteristics with the intention of the subjects to quit smoking. The subjects who spent more than a hundred rupees per week on their smoking products had an intention to quit the habit, but the ones spending lesser had no intention to quit it $(\mathrm{P}<0.005)$. The unemployed and unskilled had no intention to quit smoking compared to the employed subjects ( $\mathrm{P}$ $<0.005$ ). 
Table 3: Association of socio-demographic and habit-associated characteristics with the perception towards passive smoking and its effects

\begin{tabular}{|c|c|c|c|}
\hline \multirow[t]{2}{*}{ Characteristic } & \multicolumn{2}{|c|}{ Perception } & \multirow[t]{2}{*}{ p-value } \\
\hline & Positive No. (\%) & Negative No. (\%) & \\
\hline $\begin{array}{l}\text { Age (Years) } \\
20-30 \\
31-35 \\
36-40 \\
>40\end{array}$ & $\begin{array}{l}43(59) \\
00(00) \\
11(33) \\
32(44)\end{array}$ & $\begin{array}{l}30(41) \\
00(00) \\
22(67) \\
41(56)\end{array}$ & $0.033 *$ \\
\hline $\begin{array}{l}\text { Gender } \\
\text { Male } \\
\text { Female }\end{array}$ & $\begin{array}{l}86(48) \\
00(00)\end{array}$ & $\begin{array}{l}93(52) \\
00(00)\end{array}$ & - \\
\hline $\begin{array}{l}\text { Education } \\
\text { Uneducated } \\
\text { Educated }\end{array}$ & $\begin{array}{l}19(46) \\
67(49)\end{array}$ & $\begin{array}{l}22(54) \\
71(51)\end{array}$ & 0.804 \\
\hline $\begin{array}{l}\text { Occupation } \\
\text { unemployed } \\
\text { unskilled } \\
\text { employed } \\
\text { store owner }\end{array}$ & $\begin{array}{l}00(00) \\
36(43) \\
42(56) \\
08(47)\end{array}$ & $\begin{array}{l}04(100) \\
47(57) \\
33(44) \\
09(53)\end{array}$ & 0.097 \\
\hline $\begin{array}{l}\text { Monthly income (rupees) } \\
<6,000 \\
6,000-10000 \\
>10,000\end{array}$ & $\begin{array}{l}33(49) \\
28(44) \\
25(52)\end{array}$ & $\begin{array}{l}34(51) \\
36(56) \\
23(48)\end{array}$ & 0.662 \\
\hline $\begin{array}{l}\text { Product smoked } \\
\text { cigarettes } \\
\text { beedi } \\
\text { both }\end{array}$ & $\begin{array}{l}45(51) \\
33(45) \\
08(50)\end{array}$ & $\begin{array}{l}44(49) \\
41(55) \\
08(50)\end{array}$ & 0.740 \\
\hline $\begin{array}{l}\text { Another smoker in the family } \\
\text { Yes } \\
\text { No }\end{array}$ & $\begin{array}{l}22(51) \\
64(47) \\
\end{array}$ & $\begin{array}{l}21(49) \\
72(53)\end{array}$ & 0.639 \\
\hline $\begin{array}{l}\text { Number of children } \\
\text { one } \\
>\text { one }\end{array}$ & $\begin{array}{l}30(48) \\
56(48)\end{array}$ & $\begin{array}{l}32(52) \\
61(52)\end{array}$ & 0.947 \\
\hline $\begin{array}{l}\text { Children's age } \\
15 \text { years or less } \\
\text { More than } 15 \text { years }\end{array}$ & $\begin{array}{l}74(48) \\
12(48)\end{array}$ & $\begin{array}{l}80(52) \\
13(52)\end{array}$ & 0.996 \\
\hline $\begin{array}{l}\text { Products smoked per day } \\
0-5 \\
6-10 \\
>10\end{array}$ & $\begin{array}{l}41(49) \\
21(50) \\
24(45)\end{array}$ & $\begin{array}{l}43(51) \\
21(50) \\
29(55)\end{array}$ & 0.884 \\
\hline $\begin{array}{l}\text { Weekly expenditure (rupees) } \\
<50 \\
51-100 \\
>100\end{array}$ & $\begin{array}{l}25(47) \\
28(42) \\
33(55)\end{array}$ & $\begin{array}{l}28(53) \\
38(58) \\
27(45)\end{array}$ & 0.365 \\
\hline $\begin{array}{l}\text { Past experience } \\
\text { No problems } \\
\text { Frequent coughing } \\
\text { Shortness of breath } \\
\text { Pain or tightness in the chest } \\
\text { Problems not related to smoking }\end{array}$ & $\begin{array}{l}52(55) \\
11(32) \\
18(69) \\
05(29) \\
00(00)\end{array}$ & $\begin{array}{l}43(45) \\
23(68) \\
08(31) \\
12(71) \\
07(100)\end{array}$ & $0.001 *$ \\
\hline
\end{tabular}

$*_{p}<0.05$, chi-square 
Table 4: Association of socio-demographic and smoking characteristics with the intention to quit

\begin{tabular}{|c|c|c|c|}
\hline \multirow[t]{2}{*}{ Characteristic } & \multirow{2}{*}{$\begin{array}{c}\text { Yes } \\
\text { No. }(\%)\end{array}$} & \multirow{2}{*}{ No } & \multirow[t]{2}{*}{ p-value } \\
\hline & & & \\
\hline $\begin{array}{l}\text { Age (Years) } \\
20-30 \\
31-35 \\
36-40 \\
>40\end{array}$ & $\begin{array}{l}39(53) \\
00(00) \\
14(42) \\
36(49)\end{array}$ & $\begin{array}{l}34(47) \\
00(00) \\
19(58) \\
37(51)\end{array}$ & 0.575 \\
\hline $\begin{array}{l}\text { Gender } \\
\text { Male } \\
\text { Female }\end{array}$ & $\begin{array}{l}89(50) \\
00(00)\end{array}$ & $\begin{array}{l}90(50) \\
00(00)\end{array}$ & - \\
\hline $\begin{array}{l}\text { Education } \\
\text { Uneducated } \\
\text { Educated }\end{array}$ & $\begin{array}{l}18(44) \\
71(51)\end{array}$ & $\begin{array}{l}23(56) \\
67(49)\end{array}$ & 0.396 \\
\hline $\begin{array}{l}\text { Occupation } \\
\text { unemployed } \\
\text { unskilled } \\
\text { employed } \\
\text { store owner } \\
\end{array}$ & $\begin{array}{l}00(00) \\
33(40) \\
48(64) \\
08(47) \\
\end{array}$ & $\begin{array}{l}04(100) \\
50(60) \\
27(36) \\
09(53) \\
\end{array}$ & $0.004 *$ \\
\hline $\begin{array}{l}\text { Monthly income (rupees) } \\
<6,000 \\
6,000-10000 \\
>10,000\end{array}$ & $\begin{array}{l}31(46) \\
31(48) \\
27(56) \\
\end{array}$ & $\begin{array}{l}36(54) \\
33(52) \\
21(44)\end{array}$ & 0.554 \\
\hline $\begin{array}{l}\text { Product smoked } \\
\text { cigarettes } \\
\text { beedi } \\
\text { both }\end{array}$ & $\begin{array}{l}51(57) \\
30(40) \\
08(50) \\
\end{array}$ & $\begin{array}{l}38(43) \\
44(60) \\
08(50)\end{array}$ & 0.103 \\
\hline $\begin{array}{l}\text { Another smoker in the family } \\
\text { Yes } \\
\text { No }\end{array}$ & $\begin{array}{l}25(58) \\
64(47) \\
\end{array}$ & $\begin{array}{l}18(42) \\
72(53) \\
\end{array}$ & 0.205 \\
\hline $\begin{array}{l}\text { Number of children } \\
\text { one } \\
>\text { one }\end{array}$ & $\begin{array}{l}35(56) \\
54(46) \\
\end{array}$ & $\begin{array}{l}27(44) \\
63(54) \\
\end{array}$ & 0.190 \\
\hline $\begin{array}{l}\text { Children's age } \\
15 \text { years or less } \\
\text { More than } 15 \text { years }\end{array}$ & $\begin{array}{l}73(47) \\
16(64) \\
\end{array}$ & $\begin{array}{l}81(53) \\
09(36) \\
\end{array}$ & 0.124 \\
\hline $\begin{array}{l}\text { Products smoked per day } \\
0-5 \\
6-10 \\
>10\end{array}$ & $\begin{array}{l}40(48) \\
23(55) \\
26(49)\end{array}$ & $\begin{array}{l}44(52) \\
19(45) \\
27(51)\end{array}$ & 0.746 \\
\hline $\begin{array}{l}\text { Weekly expenditure (rupees) } \\
<50 \\
51-100 \\
>100\end{array}$ & $\begin{array}{l}20(38) \\
29(44) \\
40(67) \\
\end{array}$ & $\begin{array}{l}33(62) \\
37(56) \\
20(33) \\
\end{array}$ & $0.004 *$ \\
\hline $\begin{array}{l}\text { Past experience } \\
\text { No problems } \\
\text { Frequent coughing } \\
\text { Shortness of breath } \\
\text { Pain or tightness in the chest } \\
\text { Problems not related to smoking }\end{array}$ & $\begin{array}{l}51(54) \\
12(35) \\
17(65) \\
07(41) \\
02(29)\end{array}$ & $\begin{array}{l}44(46) \\
22(65) \\
09(35) \\
10(59) \\
05(71)\end{array}$ & 0.102 \\
\hline
\end{tabular}

$* p<0.05$, chi-square 


\section{Discussion}

While public health seeks to decrease exposure to cigarette smoke in public places, it is difficult to regulate smoking in the home ${ }^{8}$. The proportion of participants smoking indoors, even in the presence of their children was quite high (49\%). This accords with the cross-sectional survey by Blackburn et al where over $80 \%$ of these families continued to smoke in their homes despite knowing the adverse health effects of environmental tobacco smoke (ETS) exposure in children ${ }^{9}$. Parental smoking is the most important predictor of second-hand smoke or passive smoke and children from impoverished households are more likely to be exposed ${ }^{10}$. Parents of children beyond school-going age were not considered as such children are prone to tobacco smoke exposure due to active and/or peer smoking. This survey did not encounter any female smokers. Though the female population of rural India indulges in smokeless forms of tobacco, the low prevalence of smoking among them can be attributed to the fact that smoking is perceived as a male habit.

Only $44 \%$ felt that smoking caused oral cancer. Horowitz stated that there was a general lack of knowledge, with, only $25 \%$ of the sample able to identify one sign of oral cancer ${ }^{11}$. Another study found that only $14.9 \%$ of oral cancer patients were aware of its causative factors ${ }^{12}$. This shows that smokers fail to understand health problems (like oral cancer), beyond the commonly known illnesses like lung cancer.

The detrimental effects of ETS exposure include chronic respiratory symptoms, asthma, decreased lung function, and middle ear disease ${ }^{13}$. This survey, using cross-sectional data offers no direct proof that adult smoking adversely affects children's health, but only suggests the perceptions of smoking parents.

In a study by Winickoff et al, $41 \%$ of parents disagreed that their smoking had a negative effect on their child $^{14}$. Similarly in our study $37 \%$ of subjects believed that parental smoking had no harmful effect on children's health. However, $65 \%$ agreed that if they smoked in front of their children, some amount of the smoke from their cigarette would affect their children's health. This reveals the ambivalent nature of the parents towards passive smoking, on one hand, believing that it's a health threat and on the other hand, considering it harmless.

Older children have different attitudes towards parental smoking, most likely due to school health campaigns or television advertisements where they learn about the ill-effects of smoking. This is probably also why the majority (71\%) were feeling guilty when their children saw them smoke as they feared being devalued. Although unhappy about their habit, they still preferred to smoke outdoors or away from the sight of their children. Contrasting finding was reported by Chen YT et al, where only $25 \%$ of the parents felt guilty about it when seeing children's reaction or thinking of the bad impact on children ${ }^{15}$.

Emerging evidence suggests that household environments influence youth decisions about future smoking ${ }^{16}$. Not only do children model their behaviour on that of adults, but also on parental and societal attitudes towards tobacco use ${ }^{17}$. Majority expressed concerns of their children getting influenced by their smoking. This implies that there is scope for parents to set a household environment that condemns the use of smoking products, which in turn would encourage young children to cultivate intentions to remain smoke-free. It was noteworthy to find that most parents restricted themselves from smoking in the vicinity of their children by putting their cigarettes off, when they saw the discomfort it caused the children around.

Farber et al showed that most parents were receptive to taking action to reduce their child's exposure ${ }^{18}$. We also tried motivating the subjects to quit smoking and an overwhelming percentage agreed to make efforts to definitely quit smoking. While this suggests that smoking parents are concerned about the harmful effects of passive smoke and would like to quit, this might also be due to the fact that this survey might have made them respond positively to the hard-hitting information. Hence, whether they really intended to quit cannot be exactly said.

Interestingly, the subjects who had experienced smoking related health problems in the past one year had a poor perception about the harmful effects of this habit $(p<0.001)$. Despite suffering from such problems, they refused to believe the ill-effects of smoking. On the other hand, the subjects who perceived smoking as harmful were the ones who had not experienced such problems. There might be a tendency among these parents to be more careful and smoke in moderation so they could avoid health problems associated with their habit. These contradictory findings may also indicate some type of statistical artifact. However, information on several types of exposures is also needed to assess health effects of tobacco smoke and the single most important factor is to get accurate information on smoking habits of the subjects under study ${ }^{19}$. 
Parents of low socio-economic status use smoking bans at home less frequently in comparison with parents of high socio-economic status ${ }^{20}$. Compared to the employed subjects, the unemployed and the unskilled had no intention to quit smoking. In the lower socio-economic group, more smoking goes on $(\text { de Vries })^{20}$. This throws light on the fact that lower socio-economic groups do not understand the risks of smoking owing to their poor education and occupation where they find smoking as a way of coping with stress, stimulating their thinking or even relaxation from their laborious jobs. When such subjects lack the willpower to quit smoking, they also tend to be inconsiderate towards the others breathing that air.

This survey had certain limitations. The final number of subjects who participated in the survey resulted in low numbers in each area. The data presented so far covered smoking in homes with children. As this survey covers stigmatized behaviour, there could be underreporting of smoking as some parents might not have been completely forthright in describing their smoking habits, as evidenced in previous studies by Peterson et al and Seifert et $\mathrm{al}^{21}$. As we had to rely on verbal declarations regarding their smoking habit, our study may have also undercounted some homes where non-smoking was reported. Other likely reasons for non-participation could be their privacy concerns, embarrassment and lack of interest in filling out the questionnaire. Also, the figures are not comparable because parental smoking per se is only a surrogate measure as children's exposure to passive smoke is determined by various other sources as well. All responses of the subjects were self-reported behaviours or estimates and none were validated with any clinical measures.

The perception trends reported here, particularly those parents who reportedly avoided smoking around their children, suggest that if appropriate interventions are taken, they can yield successful results in reducing exposure of their children to passive smoke. Health messages about the vulnerability of children to the effects of inhaling tobacco smoke throughout their childhood need to be made more explicit to parents, who may be complacent as their children appear outwardly healthy ${ }^{22}$.

\section{Conclusions}

- Low education, unskilled jobs and past experience of smoking related health problems have an influence on the way passive smoke and its harmful effects are perceived by smoking parents in an Indian town.
- Fathers should be specifically targeted in anti-smoking campaigns with an emphasis on the importance of children's exposure to passive smoke.

- Parents with low educational attainment should be targeted by messages appropriate to their social setting, literacy and comprehension level.

\section{References}

1. Charlton A. Medicinal uses of tobacco in history. Journal of the Royal Society of Medicine 2004; 97: 292-6. http://dx.doi.org/10.1258/jrsm.97.6.292 PMid: 15173337 PMCid: PMC1079499

2. Vellappally S, Fiala Z, Smejkalova J, Jacob V, Shriharsha P. Influence of tobacco use in dental caries development. Central European Journal of Public Health 2007; 15(3):116-21.

PMid: 17958204

3. EPA designates passive smoking a "Class A" or known human carcinogen. [EPA press release January 7, 1993] Accessed on August 4, 2013.

4. World Health Organization, Division of Noncommunicable Diseases, Tobacco Free Initiative. International consultation on environmental tobacco smoke (ETS) and child health. Consultation report. 1999. Available at: http://tobacco.who.int/en/health/int-consult.html. Accessed July 11, 2013

5. Couriel JM. Passive smoking and the health of children. Thorax 1994; 49:731-4 http://dx.doi.org/10.1136/thx.49.8.731 PMid: 8091314 PMCid: PMC475114

6. Johansson A, Hermansson G, Ludvigsson J. How should parents protect their children from environmental tobacco-smoke exposure in the home? Pediatrics 2004; 113(4):291-5. http://dx.doi.org/10.1542/peds.113.4.e291

7. Passive Smoking: A summary of the evidence. May 2004. Available from: http://ash.org.uk/files/documents/ASH_305.pdf. Accessed on August 12, 2013.

8. Coxhead L, Rhodes T. Accounting for risk and responsibility associated with smoking among mothers of children with respiratory illness. Sociology of Health and Illness 2006; 28:98-121. 
http://dx.doi.org/10.1111/j.14679566.2006.0048 4.x

9. Blackburn C, Spencer N, Bonas S, Coe C, Dolan A, Moy R. Effect of strategies to reduce exposure of infants to environmental tobacco smoke in the home: cross sectional survey. British Medical Journal 2003; 327(7409):257.

http://dx.doi.org/10.1136/bmj.327.7409.257

PMid: 12896936 PMCid: PMC167160

10. Sims M, Tomkins S, Judge K, Taylor G, Jarvis MJ, Gilmore A. Trends in and predictors of second-hand smoke exposure indexed by cotinine in children in England from 1996 to 2006. Addiction 2010; 105(3):543-53.

http://dx.doi.org/10.1111/j.13600443.2009.0280

5.x

PMid: 20402999

11. Lowry RJ, Craven MA. Health promotion: Smokers and drinkers awareness of oral cancer: a qualitative study using focus groups. British Dental Journal 1999; 187(12): 668-70. http://dx.doi.org/10.1038/sj.bdj.4800363

12. Fabian MC, Irish JC, Brown DH, Liu TC, Gullane PJ. Tobacco, alcohol, and oral cancer: the patient's perspective. Journal of Otolaryngology 1996; 25(2): 88-93.

PMid: 8683658

13. Gonzales M, Malcoe LH, Kegler MC, Espinoza J . Prevalence and predictors of home and automobile smoking bans and child environmental tobacco smoke exposure: a crosssectional study of U.S.- and Mexico-born Hispanic women with young children. $B M C$ Public Health 2006; 6:265.

http://dx.doi.org/10.1186/1471-2458-6-265

PMid: 17069652 PMCid: PMC1636637

14. Hill L., Farquharson K., Borland, R. Blowing smoke: strategies smokers use to protect nonsmokers from environmental tobacco smoke in the home. Health Promotion Journal of Australia 2003; 14(3): 196-201.

15. Chen YT, Chung MC, Hsiao FH, Miao NF, Chen PL. Exploration of parental smokers' experience, perceptions, and family's influences on their smoking in the presence of children. Advances in Nursing Science 2012; 35:1-13. http://dx.doi.org/10.1097/ANS.0b013e31824455 25

PMid: 22293613
16. Ferrence R., Ashley MJ. Protecting children from passive smoking. British Medical Journal 2000; 321(7257): 310-1. http://dx.doi.org/10.1136/bmj.321.7257.310

17. Farber HJ, Knowles SB, Brown NL, et al. Second hand tobacco smoke in children with asthma: Sources of and parental perceptions about exposure in children and parental readiness to change. Chest 2008; 133(6):1367-74.

http://dx.doi.org/10.1378/chest.07-2369

PMid: 18339788 PMCid: PMC2752718

18. Pershagen G. Challenges in epidemiologic allergy research. Allergy 1997:52:1045-9.

http://dx.doi.org/10.1111/j.13989995.1997.tb001

74.x

PMid: 9404554

19. Madarasova GA, Stewart R, Van Dijk JP, Orosova O, Groothoff JW, Post D. Influence of socio-economic status, parents and peers on smoking behaviour of adolescents. European Addiction Research 2005; 11:204-9. http://dx.doi.org/10.1159/000086403 PMid: 16110228

20. Jurado D, Munoz C, de Luna JD, et al. Environmental tobacco smoke exposure in children: parental perception of smokiness at home and other factors associated with urinary cotinine in preschool children. Journal of Exposure Analysis and Environmental Epidemiology 2004; 14:330-6.

http://dx.doi.org/10.1038/sj.jea.7500329

PMid: 15254480

21. Robinson J, Kirkcaldy AJ. 'Imagine all that smoke in their lungs': parents' perceptions of young children's tolerance of tobacco smoke. Health Education Research 2009; 24:11-21. http://dx.doi.org/10.1093/her/cym080 PMid: 18156146

22. Nowatzki J, Schultz AS, Griffith EJ. Discrepancies between youth and parent perceptions of their household environment relevant to smoking: A secondary analysis of the 2004/05 Canadian Youth Smoking Survey. Chronic Diseases in Canada 2010; 30(3):78-83. 